${ }^{1}$ Honcharov Ye.V., PhD, Assoc. Prof., ${ }^{1}$ Polyakov I.V., PhD, Assoc. Prof.,

${ }^{1}$ Markov V.S., PhD, Assoc. Prof., ${ }^{1}$ Kryukova N.V., PhD,

${ }^{1}$ Boykov D.A., ${ }^{1}$ Skrebtsov N.K., ${ }^{2}$ Tsebriuk I.V., PhD, Assoc. Prof.

\title{
ANALYSIS OF MODERN POWER EFFICIENT SYSTEMS DEVELOPMENT STRATEGIES
}

\author{
${ }^{1}$ National technical university "Kharkiv politechnic institute", Kharkiv \\ ${ }^{2}$ National Academy of the National Guard of Ukraine, Kharkiv, Ukraine
}

Keywords: grid technologies, information management systems, computer technologies, energy savings.

Introduction. Development of computer technologies and Internet capabilities, emergence of achievements in the field of information and grid technologies, information and control systems based on microprocessor and power electronics, and on the other hand - the development of market relations in the economy caused a qualitative leap in energy efficiency and became a prerequisite for the development of a new kind of energy - intellectual. The concept of "smart efficiency", which reflects the intelligent interaction of pricing, production processes and efficient use of resources, has become widespread, embodied in the energy concept of "Smart Grid". Instead of the extensive development that Ukraine's economy has been moving through for decades, the energy sector should move to effectively ensure sustainable economic development. [1].

The purpose of the article. The purpose of the article is to analyze modern strategies for the development of existing information and energy systems. The task of the work is to review the methods of development and problems of theoretical research on ways to improve information and energy systems and grids.

Analysis of the power system of Ukraine. Ukraine's Unified Energy System (UUES) is the backbone of electricity that provides domestic and foreign electricity supply outside the country.

The UUES combines generating capacity and distribution grids of regions connected by $220-750 \mathrm{kV}$ transmission power lines (TPL). The production of electricity in the UUES is carried out by 14 thermal and eight hydraulic power plants, which are part of 6 state and private joint-stock power generating companies subordinated to the Ministry of Fuel and Energy of Ukraine, and four nuclear power plants (NPPs), which are part of NNEGC "Energoatom". The management of the UUES and the regimes of the grid is carried out centrally by the stateowned enterprise of NEC "Ukrenergo".

Developments in the information and energy sector of Ukraine can be divided into two classes:

a) channel solutions - which involve the use of separate components for the joint transmission of information and energy. They provide only joint information and energy transmission without intelligent management and redistribution of energy resources; 
b) grid solutions - which, in addition to transmission functions, provide for intelligent control and redistribution of both information and energy flows, which are actually geoinformation-energy systems of the highest level.

The first group includes HomePlug and HomePNA standards based communication systems for the transmission of $\sim 220 \mathrm{~V}$ AC power lines.

These standards can provide savings on the creation of information grids due to the absence of the need to create a physical medium of information transmission.

An "intelligent" electricity grid is a fully automated system that provides two-way flow of electricity and information between energy sites throughout the area (as defined by the US Department of Energy) [2, 3].

The "intelligent" electrical grid combines two grids - electrical and informationcontrol, which interact and function at the same time. At the same time, the control of each of this electrical grid devices is carried out with the help of intelligent devices, integrated into a single information and control grid [4-6].

Basic principles of building intelligent grids. The key principles for building and further expanding smart grids are plug-and-play and peer-to-peer integration of smart metering devices for the regulation, electricity storage and consumption of loads and cloud computing devices.

Plug and Play (PnP, "on" and "off") is a technology designed to quickly identify and configure devices on your computer and other technical devices.

UPnP (Universal Plug and Play) technology, a universal automatic setup for grid devices, is gaining ground. This is a peer-to-peer architecture between PCs and smart devices that automatically connects such devices to each other, making more grid accessible to more users.

Peer-to-peer (P2P) is a variant of system architecture that is based on grid of equitable nodes. Elements of a P2P computer grid can communicate directly with each other, unlike traditional architecture, when only certain categories can provide certain services to others. There is no concept of clients or servers in the P2P grid, only the level nodes that function simultaneously with other nodes in the grid.

Cloud technology is the technology of online access to server resources and the use of software by Internet users. Cloud computing is increasingly evolving.

The integration of information technology and management systems makes it possible to create new forms based on the provisions of Smart Grid:

- $\quad$ equipment Health Center - Generation of fixed assets management systems;

- $\quad$ substation self-renewal - a unified system of managing the fixed assets of the enterprise, mobile repair crews, distribution of electricity and automation of the substation;

- Intelligent Grid Management Center is a system based on the D-SCADA infrastructure (or SCADA system for the electricity distribution grid), incorporating modern control systems.

Perspective forms and directions of development of technologies "Smart Grid". Basic technologies of "intelligent" electricity:

- Monitoring and diagnostic systems (WAMS);

- Unified power flow control systems (UPFC);

- Flexible transmission technologies on alternating current (FACTS, FACDS); 
- $\quad$ Flexible AC distribution systems (FACDS);

- High-voltage direct current systems (HVDC) or with superconducting materials.

Creation of energy clusters - energy districts, which have common features, which, according to the modes of operation of the power system, provide remote flexible control of parameters by control of switching devices, which change the grid topology and conduct an assessment of the technical condition.

The scope of CE devices designed to generate predetermined levels of active and reactive power and improve power quality is being extended. The scope of the first device group is FACTS-based supply systems. The scope of the second group of devices, known as the Custom Power System (CUPS), focuses on end-user electricity distribution systems.

Electricity distribution systems can be distributed using CE devices:

- devices for ensuring compliance of parameters and connection of dispersed sources with transmission lines, for regulating the levels of electricity generation;

- devices for ensuring compliance of parameters and connection of power storage systems with transmission lines to control the exchange of electricity between them;

- devices for improving the quality of electricity supply and electromagnetic compatibility (compensation for voltage fluctuations, asymmetry, compensation for distortion of the voltage signal, phase shift).

Microgrid local systems include multiple sources and distribution substations, energy conservation complexes, and electricity flow regulators. This allows you to operate both offline and external power. Microgrid improves the reliability of energy supply by managing the rapid switching of consumers between local and central grids in the event of overloads and overvoltages.

A FREEDM-based architecture for the microgrid is also being developed, based on the concept of building a versatile ENERGYRouter device that dynamically distributes energy.

Smart Grid 2.0 technology is useful when installed smart counters are providing new pricing features and applications like Green Button.

Provide uninterrupted power supply to the facilities and integrate any power source capable transformers with an electronic chip.

Main constructing directions of intellectual grids in Ukraine. In Ukraine, serious technological modernization of power grids is required, with the use of voltage regulators and power flows. Therefore, it is important to develop appropriate regulatory and technical support for the integration of dispersed energy sources, together with the creation of the Smart Grid concept in Ukraine. Components of "intelligent" power grids in Ukraine: information interaction of control systems; unification of energy clusters, creation of intelligent electricity grid of Ukraine.

It is stated that the "intelligent" power grid must operate in real time. This is ensured by a certain organization of the information grid, the topology of which is shown in Fig. 1, where you can see that the information grid consists of two levels - local and global.

Each of these levels can also be divided into sublevels. The control center implemented at each of the levels must have sufficient computing power. After all, the main task of any control center is to ensure the smooth operation of the SCADA system (Supervisory Control and Data Acquisition) and other auxiliary software and hardware systems [7]. 


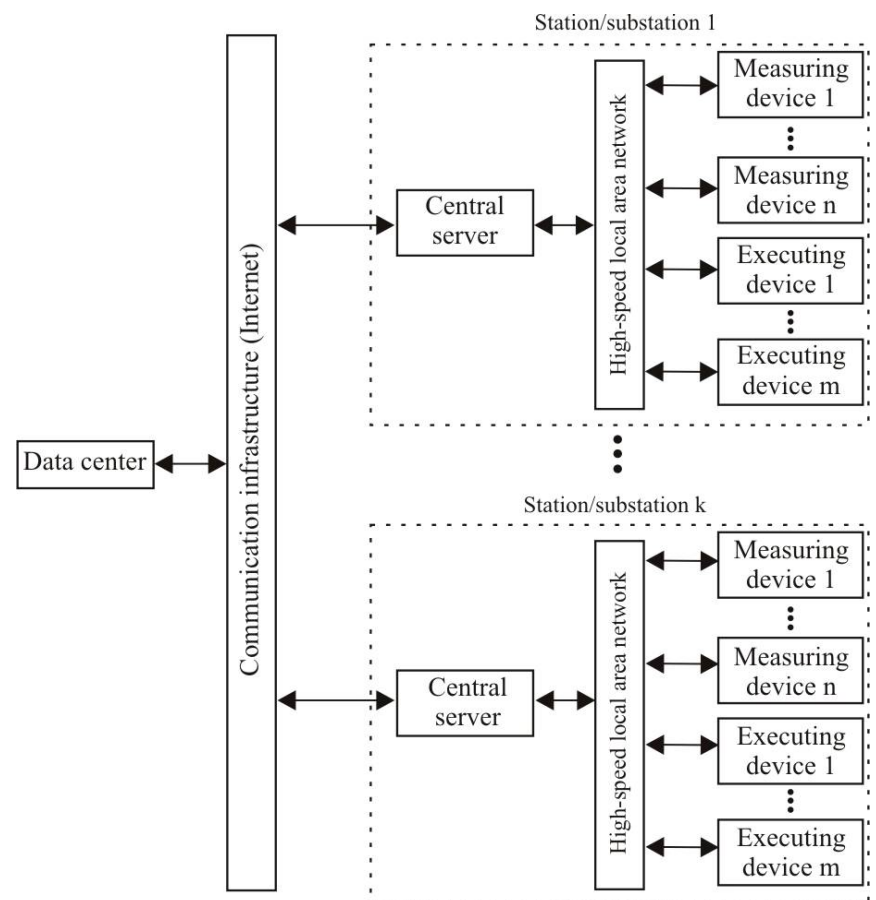

Figure 1 - Topology of information grid according to the concept of "Smart Grid"

Practical implementation of the concept "Smart Grid". The topology of the distributed "Smart Grid" electric power system of the city in is presented in Fig. 2.

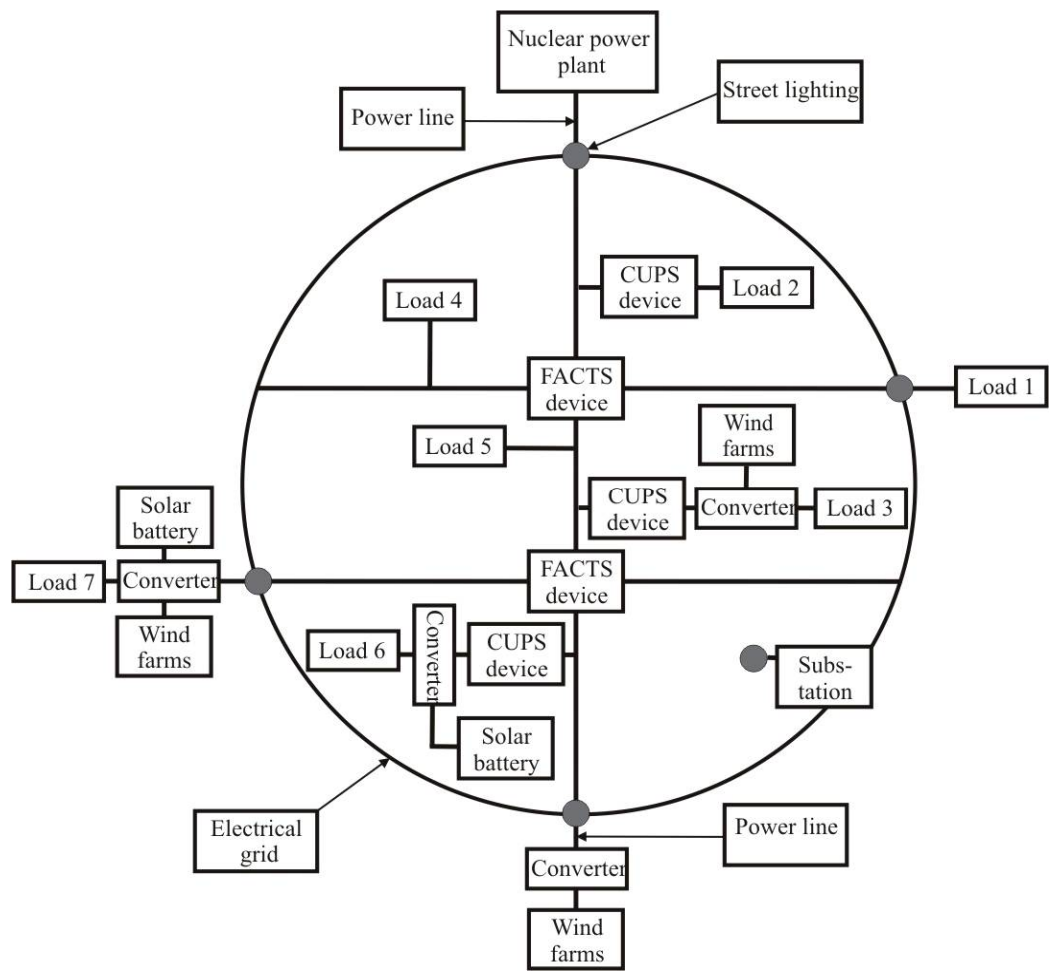

Figure 2 - Topology of the intellectual power system

Such a power system is different from the approaches that existed prior to the emergence of the "Smart Grid" concept. Any electrical grid (and the grid as a whole) was designed to be focused and peer-to-peer. This meant that there were two large classes of devices in such 
a grid: power sources and consumers of various sizes (load 1-3: big city utilities; load 4-6: smaller suburban; load 7: countryside). In such grids, electricity was only transmitted from sources to consumers, with one source supplying energy to several consumers. With the use of reconciliation devices, all power sources are combined into a single grid [8].

The topology of the "intellectual" grid, which is shown in Fig. 2, in contrast to the above, allows to integrate renewable sources of electric power of different power, as well as a large number of consumers with different nature of load (inductive, capacitive) into a single grid.

Thus, the main issue of practical implementation of the "intelligent" energy system with the specified topology is the development of equipment that would allow to connect any passive and active components to the electrical grid, to control their modes of operation, to process large amounts of information about the state of their functioning [9].

Microprocessor subsystems can simultaneously connect to an information grid to provide the operator with the necessary information in real time. The generalized structure of FACTS devices is presented in Fig. 3. From Fig. 3 implies that the reactive power exchange between the device and the power system is two-way. The FACTS is more commonly connected to one of the substation transformer phases. The scheme of measurement of electrical parameters determines the nature of the load, and such measurements are made at very short intervals.

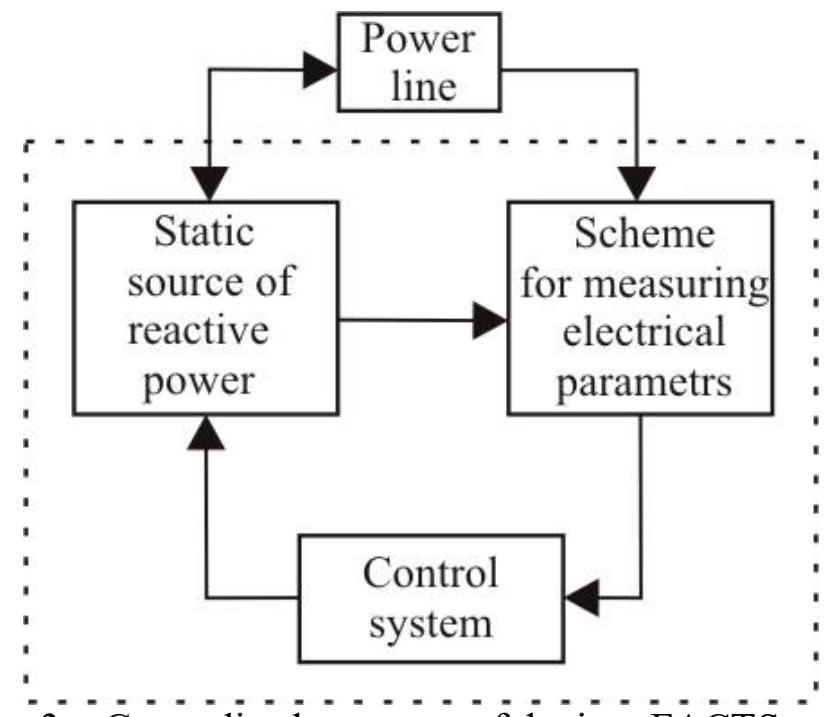

Figure $3-$ Generalized structure of devices FACTS systems

Depending on the measurement results, the control system switches to the transmission line the source of reactive power of the opposite nature [10]. Genetic algorithms can be used as algorithms for the operation of such systems, because they allow us to find the optimal value for the function of variables of many grid parameters [11].

Alternative algorithms for functioning may be "fuzzy logic" algorithms, which can be executed using artificial neural networks, which will simplify their configuration and increase performance [12]. The use of FACTS devices significantly enhances the controllability of traditional power lines in real time: regulation of voltage levels; power factor correction; reactive power compensation; regulation of transmission line capacity.

Conclusions. Thus, it should be noted that the use of sources of distributed generation can reduce the load on the electrical grid, and be located as close as possible to consumers, 
which will reduce transmission losses. In accordance with the concept of "Smart Grid", modern rechargeable energy storage devices, such as superconducting inductors, can be used.

\section{Література}

1. Стогній Б.С., Кириленко О.В., Праховник А.В., Денисюк С.П. Еволюція інтелектуальних електричних мереж та їхні перспективи в Україні // Технічна електродинаміка. 2012. №5. С. 52-67.

2. «Grids 2030». A National Vision for Electricity's Second 100 years. Office of Electric Transmission and Distribution of USA Department of Energy, 2003.

3. European Commission Directorate-General for Research Information and Communication Unit European Communities: «European Technology Platform Smart Grids, Vision and Strategy for Europe's Electricity Networks of the future», European Communities, 2006.

4. The National Energy Technology Laboratory: «A vision for the Modern Grid», March 2007.

5. News and analysis for the modernization and automation of electric power [Electronic resource]. - Access mode : http://www.smartgridnews.com.

6. Moldernik A., Bakker V., Bosman M. G. C., Hurink J. L., Smit C. G. M. Management and Control of Domestic Smart Grid Technology // IEEE Transactions on Smart Grid. 2010. № 2. P. 375-381.

7. Забезпечення надійності функціонування та стійкої роботи інтелектуальних енергетичних систем / С.П. Денисюк, П.Й. Тарасевич, О.В. Сподинський та ін. // Праці ІЕД НАНУ. 2010. № 27. С. 27-33.

8. Стогній Б.С., Кириленко О.В., Денисюк С.П. Інтелектуальні електричні мережі електроенергетичних систем та їхнє технологічне забезпечення // Технічна електродинаміка. 2010. № 6. С. 44-50.

9. Khosrow Moslehi, Ranjit Kumar Smart Grid - A Reliability Perspective // Innovative Smart Grid Technologies. 2010. № 2. P. 375-381.

10. Dapeng Wu, Chi Zhou Fault-Tolerant and Scalable Key Management for Smart Grid // IEEE Transactions on Smart Grid. 2010. №2. P. 375-381.

11. Ramaswamy P.C., Deconick G. Relevance of voltage control, grid reconfiguration and adaptive protection in smart grids and genetic algorithm as an optimization tool in achieving their control objectives // Networking, Sensing and Control. 2011. № 1. P. 26-31.

12. Yanmei Li, Jingmmin Wang, Shuangtao Li The Fuzzy Neural Network Model of Smart Grid Risk Evaluation Based on Bayes // Journal of Computers. 2011. № 1. P. 90-97.

\section{Bibliography (transliterated)}

1. Stognij B.S., Ky`ry`lenko O.V., Praxovny`k A.V., Deny`syuk S.P. Evolyuciya intelektual'ny'x elektry'chny'x merezh ta yixni perspekty'vy' $v$ Ukrayini // Texnichna elektrodynamika. 2012. № 5. P. 52-67.

2. «Grids 2030». A National Vision for Electricity's Second 100 years. Office of Electric Transmission and Distribution of USA Department of Energy, 2003.

3. European Commission Directorate-General for Research Information and Communication Unit European Communities: «European Technology Platform Smart Grids, Vision and Strategy for Europe's Electricity Networks of the future», European Communities, 2006.

4. The National Energy Technology Laboratory: «A vision for the Modern Grid», March 2007. 
5. News and analysis for the modernization and automation of electric power [Electronic resource]. - Access mode: http://www.smartgridnews.com.

6. Moldernik A., Bakker V., Bosman M G.C., Hurink J.L., Smit C.G.M.Management and Control of Domestic Smart Grid Technology // IEEE Transactions on Smart Grid. 2010. № 2. P. 375-381.

7. Zabezpechennya nadijnosti funkcionuvannya ta stijkoyi roboty` intelektual’ny`x energety`chny`x sy`stem / S.P. Deny`syuk, P.J. Tarasevy`ch, O.V. Spody`ns`ky`j ta in. // Works of the IED of the NASU. 2010. № 27. P. 27-33.

8. Stogniy B.S., Kirilenko O.V., Denisyuk S.P. Intelektualni elektrichni merezhi elektroenergetichnih sistem ta yihnye tehnologichne zabezpechennya // Texnichna elektrodynamika. 2010. № 6. P. 44-50.

9. Khosrow Moslehi, Ranjit Kumar Smart Grid - A Reliability Perspective // Innovative Smart Grid Technologies. 2010. № 2. P. 375-381.

10. Dapeng $\mathrm{Wu}$, Chi Zhou Fault-Tolerant and Scalable Key Management for Smart Grid // IEEE Transactions on Smart Grid. 2010. №2. P. 375-381.

11. Ramaswamy P.C., Deconick G. Relevance of voltage control, grid reconfiguration and adaptive protection in smart grids and genetic algorithm as an optimization tool in achieving their control objectives // Networking, Sensing and Control. 2011. № 1. P. 26-31.

12. Yanmei Li, Jingmmin Wang, Shuangtao Li The Fuzzy Neural Network Model of Smart Grid Risk Evaluation Based on Bayes // Journal of Computers. 2011. № 1. P. 90-97.

УДК 621.316 .9

Гончаров С.В., к.техн.н., доцент, Поляков І.В., к.техн.н., доцент,

Марков В.С. , к.техн.н., доцент, Крюкова Н.В., к.техн.н., доцент, Бойков Д.О., Скрєбцов М.К., Цебрюк І.В., к.техн.н., доцент

\section{АНАЛІЗ СУЧАСНИХ СТРАТЕГІЙ РОЗВИТКУ ІНФОРМАЦЙНО-ЕНЕРГЕТИЧНИХ СИСТЕМ}

У статті проведено аналіз існуючих методів розвитку і вдосконалення інформаційно-енергетичних систем. Проаналізовано низку питань щодо перспектив розвитку інформаційно-енергетичних систем та ліній електропередачі. Визначено, що основою електроенергетики є об'єднана енергетична система, яка здійснює централізоване забезпечення електроенергією внутрішніх споживачів, взаємодіє 3 енергосистемами суміжних країн, забезпечує експорт та імпорт електроенергії. Зроблено висновок, що за останні роки все більшої популярності набувають так звані “хмарні технології”. 3 аналізу сучасного стану електроенергетичної галузі слідує, що є необхідність ії модернізації та вдосконалення. Відповідно, у зв'язку з переходом світової електроенергетичної галузі на енергоефективні технології, основна увага має бути спрямована на вивчення зв'язку процесів передачі та розподілу електроенергії, а також пов'язаних з цим “інтелектуальними" вимірами, питаннями роботи енергетичних ринків та дії регулюючих норм. Відзначено, що зі створенням концепції “інтелектуальних мереж” важливо розробити відповідне нормативно-правове та технічне забезпечення інтеграції розосереджених джерел енергії з використанням наявних сучасних пристроїв силової електроніки та накопичувачів, що обумовить створення платформи керування потужностями на 
основі сучасних технологій. Відзначено, що можливість функціонування в режимі реального часу забезпечується за рахунок певної організації інформаційної мережі, а не електричної, що забезпечується за рахунок певної організації саме інформаційної мережі. Отримані результати аналізу свідчать, що інформаційний центр керування повинен мати достатню обчислювальну потужність та пропускну спроможність обчислювальної мережі, а також резервні обчислювальні потужності для забезпечення безперешкодного функціонування.

Ключові слова: мережеві технології, інформаційно-керуючі системи, комп'ютерні технології, енергоощадність.

Гончаров Е.В., к.техн.н., доцент, Поляков И.В., к.техн.н., доцент, Марков В.С. , к.техн.н., доцент, Крюкова Н.В., к.техн.н., доцент, Бойков Д.А., Скребцов Н.К., Цебрюк И.В., к.техн.н., доцент

\section{АНАЛИЗ СОВРЕМЕННЫХ СТРАТЕГИЙ РАЗВИТИЯ ИНФОРМАЦИОННО-ЭНЕРГЕТИЧЕСКИХ СИСТЕМ}

В статье проведен анализ существующих методов развития и совершенствования информационно-энергетических систем. Проанализирован ряд вопросов относительно перспектив развития информационно-энергетических систем и линий электропередачи. Определено, что основой электроэнергетики является объединенная энергетическая система, которая осуществляет централизованное обеспечение электроэнергией внутренних потребителей, взаимодействует с энергосистемами сопредельных стран, обеспечивает экспорт и импорт электроэнергии. Сделан вывод, что за последние годы все большую популярность приобретают так называемые “облачные технологии". Из анализа современного состояния электроэнергетической отрасли следует, что существует необходимость ее модернизации и совершенствования. Соответственно, в связи с переходом мировой электроэнергетической отрасли на энергоэффективные технологии, основное внимание должно быть направлено на изучение связи процессов передачи и распределения электроэнергии, а также связанных с этим "интеллектуальными" измерениями, вопросами работы энергетических рынков и действия регулирующих норм. Отмечено, что с созданием концепции “интеллектуальных сетей” важно разработать соответствующее нормативно-правовое и техническое обеспечение интеграции рассредоточенных источников энергии с использованием имеющихся современных устройств силовой электроники и накопителей, что обусловит создание платформы управления мощностями на основе современных технологий. Отмечено, что возможность функционирования в режиме реального времени обеспечивается за счет определенной организации информационной сети, а не электрической, что обеспечивается за счет определенной организации именно информационной сети. Полученные результаты анализа свидетельствуют, что информационный центр управления должен иметь достаточную вычислительную мощность и пропускную способность вычислительной сети, а также резервные вычислительные мощности для обеспечения беспрепятственного функционирования.

Ключевые слова: сетевые технологии, информационно-управляющие системы, компьютерные технологии, энергосбережение. 


\author{
Honcharov Ye.V., PhD, Assoc. Prof., Polyakov I.V., PhD, Assoc. Prof., \\ Markov V.S., PhD, Assoc. Prof., Kryukova N.V., PhD, Assoc. Prof., \\ Boykov D.A., Skrebtsov N.K., Tsebriuk I.V., PhD, Assoc. Prof.
}

\title{
ANALYSIS OF MODERN POWER EFFICIENT SYSTEMS DEVELOPMENT STRATEGIES
}

The article analyzes the existing methods and ways of developing and improving information and energy systems and grids. A number of questions are analyzed regarding the prospects for the development of information and energy systems and power lines. It has been determined that the basis of the electric power industry is the integrated energy system, which provides centralized energy supply to domestic consumers, interacts with the energy systems of neighboring countries, and ensures the export and import of electric power. It is concluded that in recent years, the so-called "cloud technologies" have become increasingly popular. From an analysis of the current state of the electric power industry, it follows that the need for its modernization and improvement. Accordingly, in connection with the transition of the world electric power industry to energy-efficient technologies, the main attention should be directed to studying the connection between the processes of transmission and distribution of electric power, as well as the related "smart" measurements, issues of the operation of energy markets and the operation of regulatory standards.. It was noted that with the creation of the concept of "smart grids", it is important to develop appropriate regulatory and technical support for the integration of dispersed energy sources using existing modern power electronics devices and storage devices, which will lead to the creation of a capacity management platform based on modern technologies. It is noted that the possibility of functioning in real time is provided due to the specific organization of the information grid, rather than an electric grid, which is provided due to the specific organization of the information grid. The results of the analysis indicate that the control information center must have sufficient computing power and bandwidth of the computing grid as well as spare computing power capacities to permanent operability assurance.

Keywords: grid technologies, information management systems, computer technologies, energy savings. 